\title{
Production of Phytotoxins, Concanamycins A and B by Streptomyces spp. Causing Potato Scab
}

\author{
Masahiro Natsume*, Rie RyU* and Hiroshi ABE*
}

Key words: Streptomyces sp., thaxtomin, concanamycin, potato scab.

Potato scab is an important disease caused by the Actinomycetes. Only a few reports have been published on the phytotoxin produced by the causal organism of common scab. Sakai et al. reported that Streptomyces spp. associated with scab of potato tuber and sugar beet produce a phytotoxic compound that inhibits the root growth of rice seedlings, but its structure was not identified $^{10)}$. Recently, thaxtomins $\mathrm{A}$ and $\mathrm{B}$ were reported by King et al. to be vivotoxins ${ }^{6,7)}$.

Antibiotic production by Actinomycetes is closely related to such morphological differentiation as aerial mycelium formation and sporulation. Repeated transplantation of $S$. griseus caused a marked decrease in streptomycin production and the appearance of nonsporulating colonies ${ }^{9}$. Mutants of S. lactamudurans which failed to produce aerial mycelium also failed to synthesize the antibiotic, cephamycin $\mathrm{C}^{3)}$. We therefore have studied the relation between phytotoxin production and aerial mycelium formation in the causal organism of common scab.

During our investigation, we found that Streptomyces sp. IFO 13767 produces phytotoxins other than thaxtomins and identified them as concanamycins A and B. We here report the isolation and identification of these concanamycins as well as their production and that of thaxtomin A in Streptomyces spp. IFO 13767 and IFO 13768 isolated from potato scab.

Procedures for the production and purification of the phytotoxins were as follows: IFO 13767 or IFO 13768 was inoculated to a $500-\mathrm{ml}$ shaking flask containing 100 $\mathrm{ml}$ of oatmeal broth medium ${ }^{1)}$, after which the flask was incubated at $28^{\circ} \mathrm{C}$ for 3 days on a reciprocal shaker $(150$ $\mathrm{rpm})$. Portions of $0.5 \mathrm{ml}$ of this culture were inoculated to petri dishes $(9 \mathrm{~cm}$ diameter) containing $10 \mathrm{ml}$ of oatmeal agar medium, and the dishes incubated at $28^{\circ} \mathrm{C}$ for 14 days. Both strains formed a few aerial mycelia, and no difference in growth was found between the strains.

The cultured material was macerated with acetone, and the acetone extract evaporated to an aqueous residue, which then was extracted with $\mathrm{CHCl}_{3}$ at $\mathrm{pH}$ 9. The $\mathrm{CHCl}_{3}$ extract was partitioned between $90 \%$ aq. $\mathrm{MeOH}$ and $n$-hexane, and the aq. $\mathrm{MeOH}$ layer evaporated to dryness. The extract was applied to a silica gel column which was flushed first with $\mathrm{CHCl}_{3}, 10 \% \mathrm{MeOH}-\mathrm{CHCl}_{3}$ then with $20 \% \mathrm{MeOH}_{-} \mathrm{CHCl}_{3}$. In the above purification procedures, authentic thaxtomin A was recovered in the $10 \% \mathrm{MeOH}^{-\mathrm{CHCl}_{3}}$ fraction.

The phytotoxic activity of the fractions in each isolation step was assayed using rice seedlings as reported by Sakai et $a l{ }^{10)}$ A sample equivalent to $10 \mathrm{ml}$ of cultured material was used for the bioassay. In both strains, phytotoxic activity was found only in the $10 \% \mathrm{MeOH}$ $\mathrm{CHCl}_{3}$ fraction from the silica gel chromatography.

Thaxtomin production in the two strains was investigated by HPLC (Develosil ODS-5, 30\% aq. $\mathrm{CH}_{3} \mathrm{CN}$, UV $220 \mathrm{~nm}$, Rt $12.5 \mathrm{~min})$. IFO 13768 produced thaxtomin A, which was confirmed by UV spectrum and phytotoxic activity of the peak fraction, whereas IFO 13767 did not produce any detectable amount of it (Table 1). This result suggests that IFO 13767 produces a phytotoxin other than thaxtomin A.

The phytotoxins produced by IFO 13767 were eluted from an ODS-HPLC column with $60 \%$ aq. $\mathrm{CH}_{3} \mathrm{CN}$ (Fig. 2 ). The peak 1 toxin showed a quasi molecular ion at $m / z 874(\mathrm{M}+\mathrm{Na})^{+}$on FAB-MS, the molecular formula of which was determined to be $\mathrm{C}_{45} \mathrm{H}_{73} \mathrm{NO}_{14}$ based on results of high resolution FAB-MS $(m / z$ 874.4962, calcd. 874.4929). The UV spectrum of peak 1 showed maxima at $\lambda_{\max } 245(\varepsilon 34,000)$ and $285(16,100)$. These data were identical with those of concanamycin $\mathrm{B}^{5)}$. Comparison of the retention time in ODS-HPLC and of the ${ }^{1} \mathrm{H}-\mathrm{NMR}$ spectrum of the peak 1 toxin with those of an authentic sample confirmed that the peak 1 toxin was concanamycin B. The peak 2 toxin showed a quasi molecular ion at $m / z 888(\mathrm{M}+\mathrm{Na})^{+}$on FAB-MS that was 14 mass units larger than that of concanamycin B. As it had the same UV spectrum $\left(\lambda_{\max } 245\right.$ ( $\varepsilon$ 31,700), 285 $(15,400))$ as concanamycin $\mathrm{B}$, it was identified as concanamycin $\mathrm{A}^{5)}$.

The production of thaxtomin $\mathrm{A}$ and concanamycins $\mathrm{A}$ and B by the two Streptomyces strains is shown in Table 1. It is noteworthy that IFO 13767 which induce common scab did not produce thaxtomin $\mathrm{A}$. We also identified these concanamycins in the extract of IFO 13767 cultured in one of the media (soluble starch-polypeptone)

\footnotetext{
* Department of Applied Biological Sciences, Tokyo University of Agriculture and Technology, Fuchu 183, Japan 農工大学農学部
} 
<smiles>CN1C(=O)[C@](O)(Cc2cccc(O)c2)N(C)C(=O)[C@@H]1Cc1c[nH]c2cccc([N+](=O)[O-])c12</smiles>

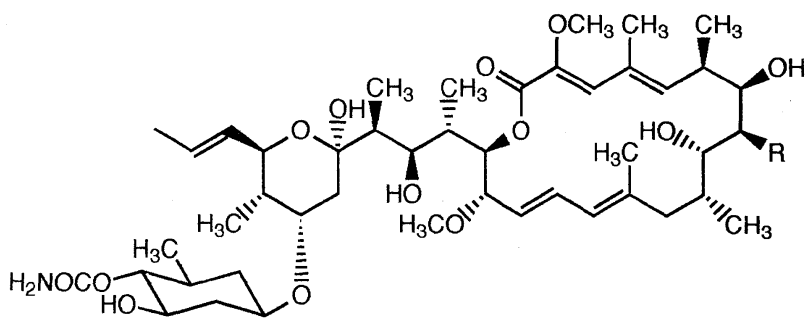

Thaxtomin A

Concanamycin $\mathrm{A}\left(\mathrm{R}=\mathrm{C}_{2} \mathrm{H}_{5}\right)$

$\mathrm{B}\left(\mathrm{R}=\mathrm{CH}_{3}\right)$

Fig. 1. Structures of thaxtomin A and concanamycins A and B.

\section{Retention time ( $\mathrm{min})$}
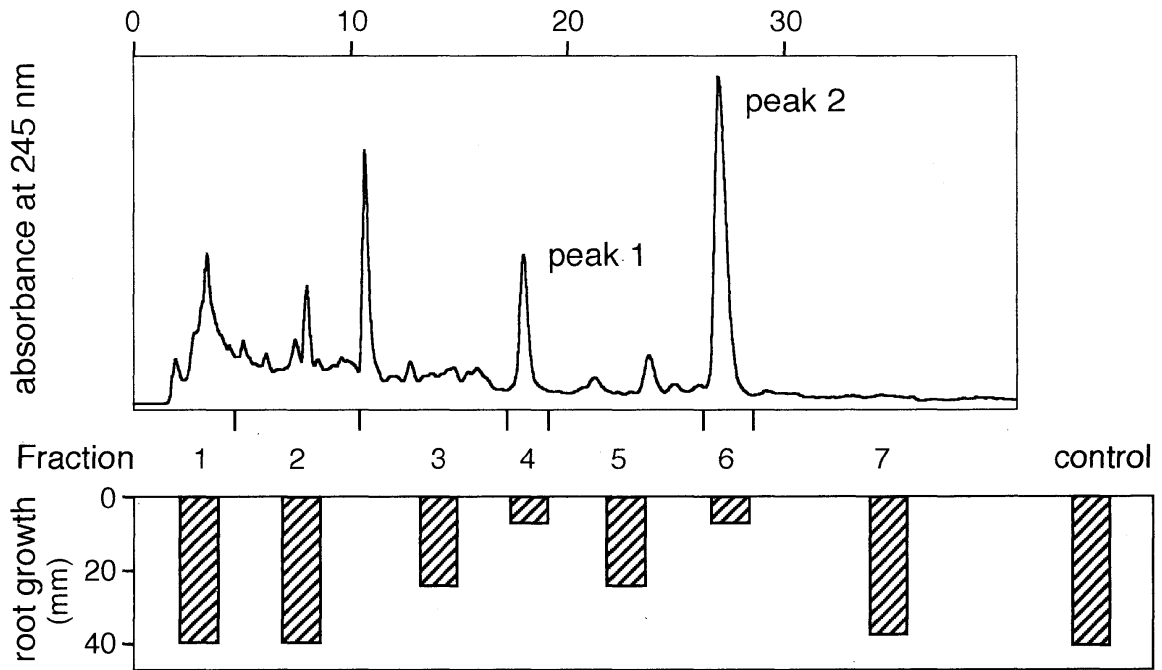

Fig. 2. HPLC purification (upper) and root growth inhibitory activity (lower) of the phytotoxins produced by Streptomyces sp. IFO 13767.

Table 1. Production of thaxtomin A and concanamycins A and B by two Streptomyces strains

\begin{tabular}{cccc}
\hline \hline \multirow{3}{*}{ Strain } & \multicolumn{3}{c}{ Production $(\mu \mathrm{g} / 1$ medium $)$} \\
\cline { 2 - 4 } & Thaxtomin & Concanamycin & Concanamycin \\
& $\mathrm{A}$ & $\mathrm{A}$ & $\mathrm{B}$ \\
\hline IFO 13767 & $\mathrm{nd}^{*}$ & 380 & 110 \\
IFO 13768 & 241 & 92 & 75 \\
\hline
\end{tabular}

* nd: not detected (less than $1 \mu \mathrm{g} / \mathrm{l}$ ).

reported by Sakai et al. ${ }^{10)}$ (concanamycin A : $900 \mu \mathrm{g} / \mathrm{l}$, concanamycin B : $5000 \mu \mathrm{g} / 1)$.

The $\mathrm{IC}_{50}$ of concanamycin $\mathrm{B}$ for the root growth of rice seedlings was $0.80 \mu \mathrm{M}$, which was comparable to that of thaxtomin $\mathrm{A}$. The $\mathrm{IC}_{50}$ of concanamycin $\mathrm{A}$ was $2.0 \mu \mathrm{M}$.

Concanamycins originally were isolated from S. diastatochromogenes as the inhibitors of the proliferation of mouse splenic lymphocytes and the growth of several fungi and yeasts ${ }^{5}$. Recently they have been shown to specifically inhibit vacuolar $\mathrm{H}^{+}$-ATPase (V-ATPase) $)^{2)}$. Inhibition of root growth by concanamycins is presumed to be due to a decrease in vacuole function caused by the inhibition of V-ATPase.

Potato scab has several classifications that are based on the appearance of symptoms; e.g. common, deep, tumulus and superficial (russet) scabs ${ }^{11}$. Streptomyces sp. IFO 13767 was isolated from infected potato with the tumulus type symptom and IFO 13768 from that with the superficial type symptom ${ }^{4}$. As thaxtomin A induces symptoms typical of the common scab disease ${ }^{8)}$, it is of interest whether concanamycins show other types of characteristic symptoms. The possibility that concanamycins induce a different type of symptoms in cooperation with thaxtomin A also needs to be examined. The relationship between the symptoms induced by Streptomyces sp. strains and the production of thaxtomins and concanamycins is now being investigated.

We thank Dr. Russell R. King, Agriculture and Agri-Food 
Canada, Fredericton, New Brunswick, Canada for providing the authentic thaxtomin A, and Prof. Akira Endo and Dr. Keiji Hasumi of our university for the ${ }^{1} \mathrm{H}-\mathrm{NMR}$ spectrum and the authentic sample of concanamycin $\mathrm{B}$.

\section{Literature cited}

1. Babcock, M.J., Eckwall, E.C. and Schottel, J.L. (1993). Production and regulation of potato-scab-inducing phytotoxins by Streptomyces scabies. J. Gen. Microbiol. 139: 1579-1586.

2. Dröse, S., Bindseil, K.U., Bowman, E.J., Siebers, A., Zeeck, A. and Altendorf, K. (1993). Inhibitory effect of modified bafilomycins and concanamycins on $\mathrm{P}$ - and V-type adenosinetriphosphatases. Biochemistry 32 : 3902-3906.

3. Ginther, C.L. (1979). Sporulation and the production of serine protease and cephamycin C by Streptomyces lactamdurans. Antimicrob. Agents Chemother. 15 : 522526

4. Kimura, S. (1976). Causal organism of a so-called Zohi-sho desease. Proc. Assoc. P1. Prot. Kyushu 22 : 5154 (in Japanese).

5. Kinashi, H., Someno, K. and Sakaguchi, K. (1984). Isolation and characterization of concanamycins $\mathrm{A}, \mathrm{B}$ and C. J. Antibiot. 37 : 1333-1343.

6. King, R.R., Lawrence, C.H., Clark, M.C. and Calhoun, L. A. (1989). Isolation and characterization of phytotoxins associated with Streptomyces scabies. J.C.S., Chem. Commun. 849-850.

7. King, R.R., Lawrence, C.H. and Calhoun, L.A. (1992). Chemistry of phytotoxins associated with Streptomyces scabies, the causal organism of potato common scab. J. Agric. Food Chem. 40: 834-837.
8. Lawrence, C.H., Clark, M.C. and King, R.R. (1990). Induction of common scab symptoms in aseptically cultured potato tubers by the vivotoxin, thaxtomin. Phytopathology $80: 606-608$.

9. Perlman, D., Greenfield, R.B., Jr. and O'Brien, E. (1954). Degeneration of a Streptomyces griseus mutant on repeated transfer. Appl. Microbiol. 2 : 199-202.

10. Sakai, R., Kawamura, H., Mino, Y., Emami-Saravi, R. and Tanii, A. (1984). Toxin production by Streptomyces spp. associated with scab of potato tuber and sugar beet I. Effect of carbon and nitrogen sources. Ann. Phytopathol. Soc. Jpn. 50 : 646-648.

11. Waksman, S.A. (1967). The Actinomycetes, Ronald Press, New York, pp. 232-237.

\section{和 文 摘 要}

夏目雅裕・龍 理恵・安部 浩：ジャガイモそうか病菌による 植物毒素 concanamycin A と B の生産

ジャガイモそうか病菌の毒素生産と菌の形態分化との関係を 解明する研究の過程で, IFO 13767 株が, これまでに本菌の生産 する毒素として構造決定されている thaxtomin A 以外の毒素 を生産していることを，イネ根の伸長阻害を指標とする生物検 定により見いだした。この毒素は HPLCによる精製で 2 種類の 成分に分離され，concanamycin A および B と同定された。そ こで IFO 13767 株と IFO 13768 株について毒素の生産性を調べ た結果，IFO 13767 株は concanamycin A および B を生産した が thaxtomin A は生産せず, IFO 13768 株は concanamycin A および B と thaxtomin A を生産していた。上記 2 菌株は異なっ た形態の病巣から単離されていることから, concanamycins の 生産性と病徵との関係に興味が持たれる。

(Received October 9, 1995; Accepted February 26, 1996) 